\title{
Dans i kroppsøvingsfaget - mer enn gode intensjoner?
}

\author{
Trond Egil Arnesen ${ }^{1 \star}$, Petter Erik Leirhaug ${ }^{2}$ og \\ Helga Aadland ${ }^{3}$ \\ ${ }^{1}$ Høgskulen på Vestlandet, campus Stord, Norway; ${ }^{2}$ Høgskulen på Vestlandet, \\ campus Sogndal, Norway; ${ }^{3}$ Høgskulen på Vestlandet, campus Stord, Norway
}

\section{Sammendrag}

Siden årtusenskiftet har dansen styrket sin posisjon i populærkulturen. Denne artikkelen undersøker om dansen i kroppsøving har styrket sin posisjon tilsvarende. Omfanget av danseundervisning i kroppsøvingsfaget studeres som en indikator på operasjonalisert lereplan og drøftes opp mot dansens posisjon i den formelle lereplan etter kunnskapsløftet. I hvilken grad gir danseundervisningens omfang elever på ulike trinn muligheter til å arbeide mot de gode intensjonene som ligger i kompetansemålene for dans?

Metodisk foretas en dokumentanalyse av læreplan i kroppsøving for å analysere dansens posisjon. Deskriptive analyser av data fra tre undersøkelser brukes til å danne et bilde av omfanget på hvert trinn i opplæringen. Til sammen tegner de tre undersøkelsene et bilde av dans i faget kroppsøving gjennom hele det 13-årige skoleløpet.

Undersøkelsen viser at dans står trygt i den formelle lereplan, men at avstanden mellom formell og operasjonalisert lereplan når det kommer til dans i kroppsøvingsfaget er, med unntak av trinn 1-4, problematisk stor gjennom hele skoleløpet. Avstanden ser ut til å øke jo høyere opp en kommer i skolesystemet. Det ser ikke ut til at de gode intensjonene med dans i kroppsøving blir oppfylt.

Nøkkelord: Kroppsøving; dans; formell lareplan; operasjonalisert lareplan.

\begin{abstract}
Since the millennium, dance has strengthened its position in popular culture in Norway. In this article, we examine if dance in physical education (PE) has strengthened its position accordingly. The amount of dance lessons in $\mathrm{PE}$ is seen as an indicator of the operationalized curriculum. The relationship between dance in the operationalized- and in the formal curriculum is being discussed. To what extent does dance in PE give pupils in various grade levels the opportunity to approach the good intentions found in the described learning outcomes for dance?

A document analysis of the PE curriculum establishes the position of dance in the formal curriculum. Descriptive analyses of data from three surveys forms a picture of the extent of dance in PE throughout the 13 years of schooling.

The study shows that dance is safely positioned in the formal curriculum, but that the gap between the formal- and the operationalized curriculum when it comes to dance in PE is, except for

^Korrespondanse: Trond Egil Arnesen, Høgskulen på Vestlandet, Postboks 1064, N-5407 Stord Norway. Email: trond.arnesen@hvl.no


grades $1-4$, problematically large. The discrepancy seems to increase the higher up one gets in the school system. It does not seem like the good intentions of dance in PE are met.

Keywords: Physical education; dance; formal curriculum; operationalized curriculum

Received: November, 2016; Accepted: April, 2017; Published: September, 2017

\section{Innledning}

Læreplanreformene i 1990-årene representerte en helt ny synliggjøring av dansens posisjon i kroppsøving sammenlignet med tidligere planverk (Nordaker, 2009). Dans ble et eget hovedområde både i grunnskolen og videregående opplæring. Men som Nordakers (2009) gjennomgang av forskning på dans i kroppsøving forteller, er det mye som tyder på at læreplanens intensjoner for dans i kroppsøving ikke fikk samme nedslag i fagpraksis. Evalueringen av Læreplanverket for den 10-årige grunnskolen (L97) (Kirke-, utdannings- og forskningsdepartementet, 1996) pekte imidlertid på at dans var i ferd med å forsterke sin posisjon som del av praksisen i kroppsøving (Jacobsen, 2003; Jacobsen et.al., 2006). Siden 1997 har dans fått mye oppmerksomhet i populærkulturen gjennom TV-program som Skal vi danse og Norske talenter, samtidig som den organiserte danseaktiviteten i Kulturskolen og i dansestudio har tiltatt i omfang. Denne studien undersøker om dansen har styrket sin posisjon i kroppsøving i samme perioden. I 2006 ble en ny læreplan for kroppsøving innført med Kunnskapsløftet (LK06) (Kunnskapsdepartementet, 2006). Vi tar for oss dansens posisjon både i LK06 og som del av undervisningspraksis i kroppsøving.

Dans blir i artikkelen forstått i vid betydning, som all bevegelsesaktivitet til musikk og rytme. Dans inngår også i musikkfaget, men denne artikkelen fokuserer bare på dansen i kroppsøvingsfaget. Det betyr også at dansen på videregående skole innen utdanningsprogram for musikk, dans, drama, samt eventuell dans innen valgfagene på trinn 8-10, ikke er inkludert.

\section{Problemstilling og teoretisk rammeverk}

Formålet er å undersøke dans som del av kroppsøving etter innføringen av Kunnskapsløftet. Fra august 2012 ble en revidert læreplan gjort gjeldene for kroppsøving (Utdanningsdirektoratet, 2012). Undersøkelsene våre ble gjennomført før revisjonen og vi forholder oss følgelig til plan for kroppsøving i LK06 gjeldene fram til august 2012 .

Som analytisk rammeverk benytter vi begrepsapparatet Goodlad og hans samarbeidspartnere (Goodlad, Klein \& Tye, 1979) utviklet for å studere sammenhengene fra læreplanen som idé til hva elevene faktisk opplever og lærer på skolen. De beskrev fem nivåer der ideenes lareplan er representert gjennom pedagogiske, politiske og samfunnsmessige diskurser og ønsker om skole, utdanning og fag. Den formelle lareplan er den til enhver tid gjeldende læreplanen, oftest et skriftlig dokument med tilhørende lovbestemmelser og veiledninger. Den oppfattede lereplan viser til hvordan planen fortolkes av lærere og andre, mens den operasjonaliserte 
lereplan sikter til gjennomføringen, hva og hvordan undervisning faktisk foregår. Den erfarte lareplan handler om hvordan elever og andre opplever den operasjonaliserte lerepl, det som skjer i undervisningen.

I denne artikkelen analyserer vi omfanget av danseundervisning i kroppsøvingsfaget som en indikator på operasjonalisert lareplan for så å drøfte den opp mot en tolkning av dansens posisjon i den formelle lareplan, slik den forelå i LK06. Problemstillingen er presisert til i hvilken grad danseundervisningens omfang gir elever på ulike trinn muligheter til å arbeide med kompetansemålene med danseinnhold. Med omfang menes antall kroppsøvingstimer med danseinnhold. Mens læreplanhistorikk og læreplananalyse får fram de faglige intensjoner med dans og dansens posisjon i den formelle lereplan, bruker vi data fra tre empiriske undersøkelser til å danne et bilde av omfanget av danseundervisning på hovedtrinnene i opplæringen. Til sammen representerer de tre undersøkelsene den operasjonaliserte lereplan for dans i kroppsøving gjennom hele det 13-årige skoleløpet.

For å kontekstualisere vår undersøkelse gis først en kort læreplanhistorisk oversikt av dans i kroppsøvingens læreplaner fram mot LK06, hvor vi også trekker inn tidligere forskning med relevans for problemstillingen. Deretter vil vi redegiøre mer detaljert for datagrunnlag, utvalg og metodisk tilnærming før vi kommer til resultatdelen. Der presenteres dans i den formelle lereplan og operasjonelle lereplan etter LK06, før problemstillingen drøftes på dette grunnlag.

\section{Dans i kroppsøvingsfaget fra 1939}

Med Normalplanen i 1939 kom dans inn som begrep i kroppsøving. Begrepet nevnes bare en gang og da som del av overskriften song og dans-leikar. Nordaker (2009) tolker dette i lys av at dans ble ansett som synd i mange pietistiske miljøer, mens lek og folkeviselek var akseptert. Selv om danserelaterte emner omtales som rytmesans og folkeleker, viser planene intensjoner om å ta inn elementer fra samtidens bevegelseskultur så vel som folkedans som kulturbevarer. For byfolkeskolen nevnes flere danser der Reinländer med turar er eksempel på konkret pensum for jentene fra 4.-7. trinn. Guttene på samme trinn er tiltenkt utvidet opplæring innen idrett. Begrunnelsen for dette skillet fremgår ikke i planverket, men i et kjønnsperspektiv sier det mye om oppfatning av dans og speiler kjønnsdimensjonen ved dans $i$ kroppsøving som et vedvarende tema. Kjønnsdimensjonen kommer i dag til syne både ved at flere jenter enn gutter ønsker mer dans, og at kvinnelige kroppsøvingslærere bruker mer tid på dans enn mannlige (Nordaker, 2009; Mattsson \& Lundvall, 2015).

Inspirert av at kroppsøving i 1936 ble vedtatt obligatorisk for alle elever skrev Hegna (1938) en bok for kroppsøvingslærere i landsfolkeskolen. Der heter det at «song- og danseleiken krev fin kroppsføring og fremjar menneskeleg umgangsgjerd» (s. 11) og den inneholder også noter til for eksempel Eg gjekk meg over sjø og land (s. 101). Som en kontrast til dette står Björkstens (1918) bok Kvinnogymnastik. Med et tabellsystem lagt tett opp til den svenske Ling-gymnastikken er rytme et vesentlig moment, men det knyttes til utførelsen av øvelser som kun gis helsefaglig 
og utviklingsmessig begrunnelse på tilsvarende måte som Ling-gymnastikken. Denne tabellstyrte, instruksjonspregede gymnastikken som reflekterte fagets helsediskurs, hadde stor innflytelse på kroppsøvingsfaglig innhold og pedagogiskpraksis i mellomkrigstiden og langt utover i etterkrigstiden.

Formuleringer om at elever skal utforske bevegelse som estetisk uttrykksform og selv skape danser ble aktualisert først med reformpedagogikkens inntog i faget fra rundt 1960 og fremover (Gurholt \& Jenssen, 2007, s. 449). Slike kreative elementer var sterkt påvirket av tidens engelske kroppsøving og inspirert av Rudolf Laban (1879-1958). Som danseartist, koreograf og teoretiker var han sentral i utviklingen av moderne dans. Elementer fra Labans (1948) analytiske begrepsapparat for dans og bevegelse kan gjenkjennes i fagplan for kroppsøving fra 1974: «Eksperimentere med rørsler som varierer i tid, styrke, høgdeplan og retning» (Kirke- og undervisningsdepartementet, 1974, s. 256).

Mønsterplanene fra 1974 og 1987 var rammeplaner hvor innholdsvalg og vektlegging av dans i kroppsøving var opp til skole og enkeltlærere. Målstyringen i læreplanreformene i 1990-årene gjorde skolene forpliktet på innhold på en ny måte, samtidig som dansen fikk styrket sin posisjon i kroppsøving (Nordaker, 2009) I Reform 1994 for videregående opplæring ble dans et eget målområde på linje med grunntrening, idrett og friluftsliv (Kirke-, utdannings- og forskningsdepartementet, 1994). L97 gir dansen i grunnskolen en tilsvarende posisjon med hovedområdene idrett og dans på mellomtrinnet og dans på ungdomstrinnet. Dans omtales både som treningsform og uttrykksform, skapende dans står presisert, men i tillegg er det en vektlegging av kulturforståelse gjennom dans: «I opplæringa skal elevane lære eit utval av internasjonale og nasjonale dansar» (Kirke-, utdannings- og forskningsdepartementet, 1996, s. 271). I L97 er alle sentrale begrunnelser for dans i tidligere planer gjenkjennbare: dans som trening og helse, dans som kulturbærer og inngang til forståelse av kulturforskjeller, samt dans som skapende og ekspressiv aktivitet.

Nordaker (2009) karakteriserer utviklingen fra L97 til LK06 som «alarmerende sett fra et dansefaglig ståsted» (s. 141). Hans analyser av norske læreplaner gir grunn til å spørre med Gard (2006) om dans inngår i kroppsøving som «simply another context in which skills are developed and a healthier life is lived» (s. 238). Nordaker (2009) analyserer også forskning og diskusjoner i fagblader, hvilket oppsummeres med at «fakta tilsier at dansen har en meget problemfylt tilværelse i kroppsøvingsfa get» (s. 157). Bakgrunnen er både hvor lite omfang noen få tallstudier indikerer at dans tilvises i kroppsøving, og et fravær av didaktiske og dansefaglige diskusjoner knyttet til faget. Selv om kartleggingen etter L97 antydet at dans var i ferd med å styrke sin posisjon som del av praksisen i kroppsøvingsfaget, og at undersøkelsen viser variasjon i inkludering av og kompetanse i dans, virker dans generelt fortsatt å stå svakt blant kroppsøvingslærere i Norge (Jacobsen, 2003; Jacobsen et.al., 2006). Norge virker på dette punkt ikke å skille seg vesentlig fra utfordringer med dans $\mathrm{i}$ kroppsøving internasjonalt (Sanderson, 1996; Mattsson \& Lundvall, 2015). I det følgende vil vi gjennomgå læreplanen som utgangspunkt for å se nærmere på Nordakers (2009) ytring om at den representerer et tilbakeskritt for de gode intensjonene med dans i kroppsøving. Deretter undersøkes en mulig utvikling av 
dansens posisjon i den operasjonaliserte lereplanen ut fra omfang av dans i faget etter LK06. Men før vi kommer til dette vil neste del redegjøre mer detaljert for utvalg og metodisk tilnærming.

\section{Datagrunnlag og metoder}

Studien sammenligner en tolkning av dansens posisjon i læreplan for kroppsøving etter LK06 med resultater fra tre ulike spørreundersøkelser som kan fortelle noe om hvor mye undervisning i dans elever møter i kroppsøving. Dokumentanalyse av læreplan i kroppsøving blir da det relevante og autentiske utgangspunkt i studien (Grønmo, 2016). Med utvikling av dans i tidligere norske læreplaner som kontekst, beskrives den formelle lereplan for dans i kroppsøving ut fra en analyse av målformuleringer med dansekarakter i LK06. Datamaterialet som danner grunnlaget for analysene av den operasjonaliserte lereplan for dans i kroppsøving er hentet fra tre ulike kvantitative undersøkelser. Skolefagsundersøkelsen 2009 gir data for trinn 8-10. Dette var en nasjonal undersøkelse blant lærere i ungdomsskolen knyttet til forskningsprosjektet «Utdanning, fag og teknologi» (Vavik et al., 2010). Fagdelen for kroppsøving (Arnesen, 2010) skulle spesielt kartlegge bruk av IKT i kroppsøving. Skolefagsundersøkelsen 2011 var en videreføring rettet mot lærere på trinn 1-7 i grunnskolen (Espeland et al., 2013). Fokus var på praktiske og estetiske fag, kroppsøving inkludert (Arnesen \& Aadland, 2013). For å danne bildet av dans på videregående trinn benyttes elevdata fra et doktorgradsprosjekt som studerte vurdering for lcering i kroppsøving ved seks videregående skoler (Leirhaug, 2016). For dette trinn gir materialet ikke grunnlag for å trekke konklusjoner om andre skoler enn de seks som er undersøkt.

Ingen av undersøkelsene er utformet for å innhente data i forhold til dans spesielt, men de var utformet med utgangspunkt i læreplan og fagdidaktisk teori for å gi et bredt bilde av kroppsøving, noe som inkluderte spørsmål om kompetanse og omfang relatert til dans i kroppsøving. Noen av resultatene (tabell 2) er tidligere presentert i kroppsøvingsdelen (Arnesen \& Aadland, 2013) av Skolefagsundersøkelsen 2011, men da for å si noe om innholdet i kroppsøving, på trinn 1-7, i bredden av faget, mens resultatene her blir brukt for å si noe om spesifikt om dans.

Undersøkelsene har ulikt design og spørsmålsstillingene er forskjellige. Materialet tillater derfor ikke direkte sammenligninger mellom trinn på tvers av undersøkelsene. Følgelig bruker vi datamaterialet fra undersøkelsene uavhengig til å danne bilder av omfanget på hvert trinn, for deretter å drøfte om dette virker å gi et rimelig grunnlag for å arbeide med kompetansemålene på respektive trinn. Datainnsamling for trinn 8-10 ble gjennomført i 2008/2009, for trinn 1-7 i $2011 \mathrm{og}$ for videregående skole i 2011/2012. Datamaterialet er altså innhentet før revidert læreplan i kroppsøving trådde i kraft fra august 2012. Statistiske analyser (De Vaus, 2014) er gjort med IBM SPSS Statistics 22 og 23.

Utvalget som ligger til grunn for resultatene på videregående trinn består av de 1486 elevene som har svart på spørreskjema (svarprosent: 72,6 \%). Utvalget i kroppsøvingsdelen av Skolefagsundersøkelsen 2009 omfatter 77 lærere (33 kvinner, 44 menn) 
fra 33 ulike ungdomsskoler. $50 \%$ av lærerne har minst årsstudium i kroppsøving, $9 \%$ har ingen utdanning i faget. I Skolefagsundersøkelsen 2011 for trinn 1-7 er det totalt 173 lærere (112 kvinner, 61 menn) som har svart på kroppsøvingsdelen. 164 av lærerne har valgt hovedtrinn, 84 på trinn 1-4 og 80 på trinn 5-7, hvilket utgiør utvalget i analysen hvor disse sammenlignes. Omfanget av kroppsøvingsutdanning for lærerne på trinn 1-7 viser at $23 \%$ har ingen utdanning, mens $45 \%$ har årsstudium eller mer.

Utdanningsnivået i kroppsøving for grunnskolelærerne ligger i materialet over tidligere tall for hele populasjonen hvor $41 \%$ av de som underviste i kroppsøving ikke hadde utdanning i faget (Lagerstrøm, 2007). Grunnen til dette er trolig selvseleksjon av fag. Respondentene på kroppsøving er sannsynligvis lærerne som i størst grad identifiserer seg med faget, hvilket kan gi resultatene en skjevhet i retning av mer kvalifiserte og oppdaterte svar.

I tillegg til svakheter som alltid følger selvrapportering (Koziol \& Burns, 1986) og tidligere nevnte utfordringer ved at undersøkelsene er forskjellige og ikke primært utformet for å kartlegge dans i den operasjonelle lereplan, har denne studien to vesentlige begrensninger som resultat og konklusjoner må leses i lys av. Utvalgsstørrelsen er liten $i$ alle tre undersøkelsene, selv om det altså bare er for videregående skole at utvalgskriteriene ikke inkluderer representativitet. Videre sier en studie av omfang ikke noe om kvaliteten på den opplæring i dans som faktisk foregår. LK06 fokuserer på kompetansen elevene skal oppnå og gir få retningslinjer for undervisningsomfang. For å belyse dansens posisjon i faget best mulig med omfang som utgangspunkt, har vi i resultatpresentasjonen inkludert rapportering av omfang av andre aktiviteter. Totalt sett representerer resultatene et mulig bilde av den operasjonaliserte lereplan for dans i kroppsøving. Dette bildet er basert på analyse av deskriptiv statistikk, og vil etter en gjennomgang av dans i den formelle lereplan presenteres i kommenterte frekvenstabeller separat for trinn $1-7$, trinn $8-10$ og videregående skole.

\section{Dans i LK06 - den formelle læreplan for dans i kroppsøving}

Den generelle delen av læreplanen ble vedtatt i 1993 og videreført i LK06. I den heter det at «menneskets formidling ved kropp og sinn, i idrett, kunst og håndverk, i språk og litteratur, i teater, sang, musikk og dans er viktige sider ved vår kulturtradisjon som skolen skal ivareta» (Kirke-, utdannings- og forskningsdepartementet, 1996, s. 23). Evnen til innlevelse og uttrykk, sentrale kompetanser innen utøving og formidling av kulturuttrykk, er vektlagt. Hovedansvaret for opplæring i dans tillegges fagene kroppsøving og musikk, men sitatet viser at dans i den formelle lereplan er en del av kulturfeltet og et anliggende for skolen som helhet.

Kroppsøving er et fag med ambisjoner om å skape bevegelsesglede og gi elevene kompetanse innen sentrale deler av samfunnets bevegelseskultur. Formålet for faget sier at leik, idrett, dans og friluftsliv er en del av felles danning og identitetsskaping $i$ samfunnet. Kroppsøving som allmenndannende fag skal medvirke til at mennesket sanser, opplever, lærer og skaper med kroppen. Faget skal «inspirere til rørsle, kreativitet og sjølvstende hos den einskilde» (Kunnskapsdepartementet, 2006), og dans plasseres som en sentral del av faget der elevene ut fra egne forutsetninger 
skal kunne oppleve mestring og mestringsglede. Sammen med idrettsaktivitet eller idrett utgiør dans et eget hovedområde i kroppsøving fra trinn 5-13 (tabell 1).

Faget kroppsøving har for trinn 1-4 et felles hovedområde, aktivitet $i$ ulike bevegelsesmiljø. Dette har 17 kompetansemål hvor 2 har tydelig dansekarakter: «utforske og leike med ulike rytmar og uttrykkje de med rørsler» og «vera med i songleikar og enkle dansar frå ulike kulturar» (Kunnskapsdepartementet, 2006).

Det presiseres at idrettsaktivitet og dans på trinn 5-7 innebærer deltakelse i både skapende og utøvende danser, og at eksperimentering og fri aktivitet er sentrale aktivitetsområder. Av de 15 kompetansemålene for trinn 5-7, handler de to målene for dans om å delta i danser fra ulike kulturer, lage enkle danser og eksperimentere med rytmer og bevegelser.

Hovedområde idrett og dans for trinn 8-13 omfatter et bredt utvalg av danser. I tillegg til deltagelse blir framføring av danser trukket fram, både av egenproduserte og fra ulike kulturer, deriblant ungdomskulturene.

Med 5 av 15 kompetansemål på trinn 8-10 kan det argumenteres for at det er på dette trinnet dans står sterkest i den formelle lereplan (tabell 1). Kompetansemålene for trinn 8-10 slår fast at eleven skal kunne danse danser fra norsk kulturtradisjon og andre kulturer. Eleven skal kunne skape dans og delta i danser som andre har laget, samt utføre danser fra ungdomskultur. Eleven skal kunne planlegge og lede danseaktiviteter sammen med medelever og vurdere erfaringer fra dans.

Læreplanmodellen i LK06 forventer progresjon der kompetansen på et trinn bygger på det forrige. Det er vanskelig å se en slik progresjon innen dans, spesielt mot slutten av skoleløpet. Elevene skal skape, lede og vurdere dans etter 10. trinn. Det ligger ingen uttalt progresjon fra dette, til å praktisere dans fra ulike kulturer eller å skape dansekomposisjoner på Vg1. I Vg2 handler kompetansen om å utarbeide og gjennomføre treningsopplegg med sikte på å forbedre ferdigheter i idrett og dans, og for Vg3 foreligger ikke kompetansemål som spesifikt omtaler dans. Totalt er 3 av 25 kompetansemål på videregående trinn direkte knyttet til dans.

Til tross for at det mangler en tydelig progresjon for dans, og at kompetansemålene er ujevnt fordelt mellom hovedtrinnene, så er dans godt befestet i den formelle lareplan for kroppsøving. Dans er presisert i formålet, den er en del av hovedområder i faget, og det er 12 av 72 kompetansemål som dekker dans.

Tabell 1. Hovedområder i kroppsøving i LK06 (gjeldene til 01.08.2012) og antall kompetansemål med dans.

\begin{tabular}{|c|c|c|c|c|c|}
\hline \multirow{2}{*}{$\frac{\text { Trinn }}{1-4}$} & \multicolumn{3}{|c|}{$\begin{array}{c}\text { Hovedområde i } \\
\text { kroppsøvingsfaget i LK06 }\end{array}$} & \multirow{2}{*}{$\begin{array}{c}\begin{array}{c}\text { Kompetansemål } \\
\text { med dansekarakter }\end{array} \\
2\end{array}$} & \multirow{2}{*}{$\frac{\begin{array}{c}\text { Totalt antall } \\
\text { kompetansemå }\end{array}}{17}$} \\
\hline & Aktivitet i ulike & pevegelsesm & & & \\
\hline $5-7$ & Idrettsaktivitet & g dans & Friluftsliv & 2 & 15 \\
\hline $8-10$ & Idrett og dans & Friluftsliv & Aktivitet og livsstil & 5 & 15 \\
\hline $11-13$ & Idrett og dans & Friluftsliv & Trening og livsstil & 3 & 25 \\
\hline $1-13$ & & & & 12 & 72 \\
\hline
\end{tabular}




\section{T. E. Arnesen et al.}

Dans er ikke et ferdigskrevet kulturuttrykk i den formelle lereplan, det må fylles med handling, mening og verdi gjennom lokal tolkning av læreplanen. Enkeltlærere og skoler vil operasjonalisere læreplanen ut fra lokal kompetanse og praksisteori. Den operasjonaliserte lereplan vil i innhold og pedagogisk tilnærming derfor variere mellom skoler og mellom lærere.

\section{Den operasjonaliserte læreplan for dans i kroppsøving}

\section{Trinn 1-7}

For å få et overblikk over innholdet i faget ble lærerne i Skolefagsundersøkelsen 2011 spurt om å rapportere timer brukt i snitt per år til ulike aktiviteter (tabell 2). Grunnet ulikt timetall er det umulig å sammenligne hovedtrinnene statistisk, derfor er tabellen

Tabell 2. Gjennomsnittlig timetall brukt til ulike aktiviteter $\mathrm{i}$ året per klasse, og rangering av aktivitet basert på timetall (Arnesen \& Aadland, 2013, s. 48).

\begin{tabular}{|c|c|c|c|c|}
\hline & $\begin{array}{c}\text { Rangering } \\
\text { basert på } \\
\text { timetall på } \\
\text { trinn } 1-4\end{array}$ & $\begin{array}{l}\text { 1.-4. trinn: } \\
\text { gjennomsnittlig } \\
\text { timetall til } \\
\text { aktivitet }\end{array}$ & $\begin{array}{l}\text { Rangering } \\
\text { basert på } \\
\text { tidsbruk på } \\
\text { trinn } 5-7\end{array}$ & $\begin{array}{c}\text { 5. }-7 . \text { trinn: } \\
\text { gjennomsnittlig } \\
\text { timetall til } \\
\text { aktivitet }\end{array}$ \\
\hline $\begin{array}{c}\text { Arbeid med grunnleggende } \\
\text { bevegelser i variert miljø }\end{array}$ & 1 & 5,30 & 1 & 4,71 \\
\hline Organisert lek & 2 & 5,29 & 2 & 4,71 \\
\hline Arbeid med småredskap & 3 & 4,41 & 9 & 3,94 \\
\hline Svømming og livberging i basseng & 4 & 4,29 & 12 & 3,66 \\
\hline Arbeid med store apparat & 5 & 4,18 & 11 & 3,82 \\
\hline Fri lek & 6 & 4,05 & 17 & 3,03 \\
\hline Kanonball/stikkball & 7 & 3,95 & 3 & 4,62 \\
\hline Utforsking av rytmer og bevegelser & 8 & 3,76 & 16 & 3,05 \\
\hline $\begin{array}{l}\text { Ski, inkludert langrenn, } \\
\text { brett, alpint, telemark }\end{array}$ & 9 & 3,70 & 13 & 3,66 \\
\hline Fotball & 10 & 3,68 & 8 & 4,25 \\
\hline Friidrett & 11 & 3,63 & 4 & 4,38 \\
\hline Turn & 12 & 3,22 & 14 & 3,38 \\
\hline Sangleker og dans fra andre kulturer & 13 & 3,12 & 23 & 2,39 \\
\hline Utholdenhetstrening inkludert jogging & 14 & 3,09 & 5 & 4,34 \\
\hline Styrketrening inkludert basistrening & 15 & 3,05 & 6 & 4,34 \\
\hline Volleyball, basket, håndball & 16 & 3,05 & 7 & 4,32 \\
\hline Innebandy & 17 & 2,87 & 10 & 3,89 \\
\hline $\begin{array}{l}\text { Aerobic og andre rytmiske } \\
\text { treningsformer til musikk }\end{array}$ & 18 & 2,66 & 18 & 2,86 \\
\hline Skøyter & 19 & 2,59 & 20 & 2,53 \\
\hline Orientering & 20 & 2,56 & 15 & 3,05 \\
\hline Folkedans & 21 & 2,41 & 22 & 2,42 \\
\hline Elevene lager egne danser & 22 & 2,40 & 21 & 2,44 \\
\hline Sykling/trafikkopplæring & 23 & 2,09 & 19 & 2,71 \\
\hline Tennis, badmington, bordtennis & 24 & 1,82 & 24 & 2,22 \\
\hline
\end{tabular}


laget for å visualisere prioriteringen på de to hovedtrinnene. Dette gjøres ved å vise timetall brukt på aktivitetene og en rangering av aktivitetene basert på tidsbruken. Det er viktig å være klar over at en time i kroppsøving ikke nødvendigvis er en klokketime og at det ofte blir utøvd flere ulike aktiviteter i samme time. Rapporteringen kan derfor være vanskelig for lærerne, og resultatene må leses i lys av dette.

Tabell 2 synliggiør forskjeller mellom hovedtrinnene i operasjonalisert lareplan. Hovedtrinn 1-4 er tydelig dominert av arbeid med de grunnleggende bevegelsene, organisert lek og fri lek. Utforsking av rytmer og rørsler kommer på åttende plass, men før alle de tradisjonelle konkurranseidrettene. Sangleker og dans fra andre kulturer, det andre av kompetansemålene innen dans på hovedtrinnet, blir rangert på en 13. plass. Andre danseaktiviteter som ikke er direkte knyttet til kompetansemålene for hovedtrinnet blir mindre brukt. Aerobic på 18. plass, folkedans på 21. og elever lager egne danser på 22. plass. På trinn 5-7 videreføres innholdskomponentene i dans fra trinn 1-4 med litt andre formuleringer, men de blir mindre arbeidet med og faller på rangeringen ned til 16. og 23. plass. Arbeidet med det nye elementet i kompetansemålene, elever lager egne danser, blir rangert på 21. plass.

\section{Trinn 8-10}

Når lærerne i Skolefagsundersøkelsen 2009 rapporterer tid brukt til dans i den operasjonaliserte lareplan på trinn 8-10 (tabell 3), kommer det fram at $73 \%$ bruker mindre enn $20 \%$ av tiden til dans, mens $0 \%$ bruker mindre enn $20 \%$ av tiden på idrett. Så mange som $86 \%$ bruker fra $40-100 \%$ på idrett, $1,4 \%$ bruker tilsvarende på dans. Ser vi på enkeltidretter så bruker lærerne gjennomsnittlig mer tid til sammen på friidrett og fotball, enn på hele bredden av dansefeltet. For friluftsliv og aktivitet og livsstil rapporterer lærerne om høyere tidsbruk enn for dans, men langt under tidsbruken til idrett.

Av ulike danseaktiviteter (tabell 4), er det aerobic og det at elevene lager egne danser som er mest brukt. Nesten $20 \%$ av lærerne har disse aktivitetene fra fem til ni ganger $\mathrm{i}$ året. I andre enden av skalaen finner vi dans fra andre kulturer som over $90 \%$ av lærerne har to eller færre ganger i året. Om lag en fjerdedel av lærerne har moderne dansdans fra ungdomskulturen mer enn tre ganger $\mathrm{i}$ året.

Tabell 3. Trinn 8-10: lærernes prosentdel av undervisningstid til ulike aktivitetsområder. Lærersvar i prosent.

\begin{tabular}{lcccc}
\hline $\begin{array}{l}\text { Prosentdel av undervisningstid } \\
\text { til ulike aktivitetsområder }\end{array}$ & Dans & Idrett & Friluftsliv & Aktivitet og livsstil \\
\hline $0-20 \%$ & $73 \%$ & 0 & $64,9 \%$ & $41,9 \%$ \\
$20-40 \%$ & $25,7 \%$ & $16 \%$ & $27 \%$ & $43,2 \%$ \\
$40-60 \%$ & $1,4 \%$ & $41,3 \%$ & $4,1 \%$ & $14,9 \%$ \\
$60-80 \%$ & 0 & $37,3 \%$ & $1,4 \%$ & 0 \\
$80-100 \%$ & 0 & $5,3 \%$ & $2,7 \%$ & 0 \\
\hline
\end{tabular}




\section{T. E. Arnesen et al.}

Tabell 4. Antall timer $\mathrm{i}$ året hver av dine kroppsøvingsklasser gjennomsnittlig har undervisning i følgende aktiviteter. Lærersvar i prosent.

\begin{tabular}{lrrrrrr}
\hline & 0 & $1-2$ & $3-4$ & $5-6$ & $7-9$ & 10 og mer \\
\hline Elevene lager egne danser & $9,3 \%$ & $45,3 \%$ & $26,7 \%$ & $14,7 \%$ & $4 \%$ & \\
Folkedans & $20,3 \%$ & $54,1 \%$ & $17,6 \%$ & $5,4 \%$ & $1,4 \%$ & $1,4 \%$ \\
Dans fra andre kulturer & $34,7 \%$ & $56 \%$ & $6,7 \%$ & $1,3 \%$ & $1,3 \%$ & \\
Moderne dansdans fra ungdomskulturen & $15,1 \%$ & $58,9 \%$ & $21,9 \%$ & $2,7 \%$ & $1,4 \%$ & \\
Aerobic og andre rytmiske treningsformer til musikk & $13,3 \%$ & $40 \%$ & $29,3 \%$ & $13,3 \%$ & $4 \%$ & \\
\hline
\end{tabular}

\section{Videregående skole}

Elevene ved de seks videregående skolene som inngår i undersøkelsen ble spurt om å krysse av for hvor ofte de har ulike aktiviteter i kroppsøvingsfaget eller som del av aktivitetsdager. Tabell 5 har samlet spørsmålene knyttet til dans og presenterer prosentvis fordeling av elevenes svar på disse. Mellom 56,3 \% og 71,6 \% av elevene rapporterer at de aldri i løpet av siste året har hatt danseaktiviteter som kompetansemålene eksplisitt legger opp til. Mellom 6,6 \% og 11,4 \% av elevene sier de i løpet av siste året har hatt de ulike danseaktivitetene tre eller flere ganger.

Elevene ble også bedt om å ta stilling til påstander om undervisning og læringsutbytte i kroppsøving ved å rapportere på en femdelt skala fra helt enig til helt uenig. Svar på påstanden jeg larer ulike danser støtter inntrykkene fra tabell 5: 62,8 \% av elevene er uenig eller helt uenig i påstanden, mens 14,6 \% sier seg enig eller helt enig. Videre er $67 \%$ av elevene er helt uenig eller uenig i påstanden vi har for mye dans.

\section{Oppsummering og drøfting}

Den generelle delen av LK06 presenterer dans som en del av vår skapende tradisjon, og i formålet for kroppsøving trekkes dans fram som en del av allmenndannelsen og et identitetsskapende element i samfunnet. Det var riktignok flere målformuleringer for dans i læreplanene fra 1990-årene, men den korte formen som var krevd i LK06 gjorde at det på alle områder av faget ble kuttet ned. Nordaker $(2009,2010)$ påpeker at det ble vanskelig å lese dansens formål ut fra kompetansemålene i LK06, men vi vil argumentere for at det hovedsakelig er utformingskravene for læreplanene i LK06 som får Nordaker (2009) til beskrive reduksjonen fra L97 som dansefaglig alarmerende.

Tabell 5. Videregående elevers svar på spørsmål om hvor ofte har du i løpet av det siste året i kroppsøving eller på aktivitetsdager hatt disse aktivitetene? Elevsvar i prosent $(n=1486)$.

\begin{tabular}{lccccc}
\hline & Aldri hatt & $1-2$ & $3-4$ & $5-10$ & Mer enn 10 \\
\hline Dans du selv er med på å lage & $57,6 \%$ & $34,4 \%$ & $4,8 \%$ & $2,0 \%$ & $1,2 \%$ \\
Norsk folkedans (f. eks. reinlender, polka, halling) & $71,6 \%$ & $21,9 \%$ & $5,0 \%$ & $0,9 \%$ & $0,7 \%$ \\
Dans fra andre kulturer & $67,4 \%$ & $25,2 \%$ & $5,5 \%$ & $1,0 \%$ & $0,9 \%$ \\
Aerobic og andre former for musikkmosjon & $56,3 \%$ & $32,2 \%$ & $8,8 \%$ & $1,7 \%$ & $0,9 \%$ \\
\hline
\end{tabular}


De innholdskomponentene og gode intensjonene som i var formulert for dans i R94 og L97 kan finnes igjen i kortform i LK06. Og med 12 av totalt 72 kompetansemål i den formelle lereplan vil vi hevde at dans fortsatt står trygt plassert i kroppsøving, og at læreplanen derfor kan tolkes som en videreføring av de gode intensjonene på dansens vegne i 1990-åras læreplaner.

For å undersøke operasjonalisert lereplan for dans spurte vi etter tid brukt til undervisning $\mathrm{i}$ dans som en indikator. Lærerne på trinn 1-4 rapporterte over tre timer i snitt per år på de to kompetansemålene med danseinnhold. I tillegg ble også andre danseaktiviteter brukt i en viss utstrekning. Undersøkelsen kan ikke si noe om kvaliteten i arbeidet, men dette er et omfang som vi mener åpner for at elevene kan få jobbe meningsfullt med kompetansemålene. Der (Jacobsen, 2003; Jacobsen et al., 2006) konkluderte med at det var på trinn 1-4 det så ut som om danseundervisningen var mest mangelfull, tyder funnene i denne studien på at det er på dette trinnet elevene har best muligheter for å jobbe med kompetansemålene.

Den positive tendensen på trinn 1-4 finner vi ikke igjen i operasjonalisert lereplan for trinn 5-7. Omfanget av tid rapportert brukt til dans går ned samtidig som totalt timetall går opp på trinn 5-7. Dette tolker vi til at det er lite trolig at flertallet av elevene får tilstrekkelig tid til å jobbe med kompetansemålene, med tanke på å tilegne seg kompetansen foreskrevet i den formelle lareplan. At det å lage sine egne danser er rangert helt nede på 21 plass av aktivitetene i faget og at det gjennomsnittlig bare blir jobbet med kompetansemålet i 2,4 timer, forteller at mange elever ikke får mulighet til å utvikle denne kompetansen. Det at danseaktivitetene i tidsbruk blir rangert mellom 16. og 23. plass av 24 aktiviteter viser at det er langt igjen før dansen i den operasjonaliserte lereplan har den posisjonen den tilskrives i den formelle lereplan på trinn 5-7.

På trinn 8-10 rapporterer lærerne at de andre kompetanseområdene i den operasjonaliserte lereplan kommer i skyggen av idretten, særlig gjelder dette for dans og friluftsliv, mens aktivitet og livsstil kommer bedre ut. Det at $73 \%$ av lærerne bruker $20 \%$ eller mindre av tiden til dans når en tredjedel av kompetansemålene er knyttet til dans, mens ingen bruker tilsvarende lite på idrett understreker dette. Men det er viktig å understreke at antall kompetansemål ikke er likt et visst antall timer, poenget er at elevene skal lære seg det kompetansemålene foreskriver. Resultatene peker $\mathrm{i}$ retning av at det er mange norske elever som ikke vil oppnå dette, særlig gjelder dette kompetansemålet med dans fra andre kulturer der over en tredjedel av lærerne sier at de ikke har dekket kompetansemålet i undervisningen. Når under $10 \%$ av lærerne har undervist i dette mer enn to timer $\mathrm{i}$ året pr. klasse, så er dette et kompetansemål som $\mathrm{i}$ stor grad er tilsidesatt. For kompetansemål om folkedans og ungdomskulturell dans er situasjonen nesten like dårlig. Best er situasjonen for kompetansemålet der elevene skal lage egne danser, men også her er det over halvparten av elevene som får jobbe med målet to eller færre timer $i$ året. Analysen indikerer at det for trinn 8-10 er så stor avstand mellom formell og operasjonell lereplan at vi for det trinnet, hvor dans er sterkest representert med kompetansemål i den formelle lereplan, vil konkludere med at dette ikke blir reflektert i omfang i den operasjonelle lareplan. 


\section{T. E. Arnesen et al.}

Gjennom å være representert i hovedområdet og ha 3 av 25 kompetansemål er dans like godt representert i den formelle lereplan på videregående skole som på trinn 1-7. Det er trinn 8-10 som skiller seg ut med flere kompetansemål. Dette kan være litt av grunnen til at omfanget i den operasjonaliserte lereplan ser ut til å være enda mindre enn på trinn 8-10. Til tross for denne forskjellen i posisjon mellom hovedtrinnene i LK06, virker forskjellen mellom formell og operasjonalisert lereplan for de fleste elevene, ved de seks videregående skolene, uholdbar stor. For å kunne ha en reell mulighet til å arbeide skikkelig med kompetansemålene, mener vi elevene bør ha en danseaktivitet minimum tre ganger i løpet av det siste året. Det gjelder bare mellom 6,6\% og $11 \%$ av elevene. Når over halvparten av elevene sier at de ikke har hatt danseaktivitetene i hele tatt, så er det langt igjen før dansen i kroppsøvingsfagets operasjonaliserte lereplan har fått den plassen den blir tilskrevet i den formelle lereplan. Men her må vi ta et forbehold fordi utvalget med elever fra seks videregående skoler ikke er representativt. Det er også et begrenset antall lærere i undersøkelsen (Leirhaug, 2016). Lærere som formelt sett er godt utdannet innen kroppsøving, men som av ulike grunner i stor grad utelukker dans fra sin undervisning. Dette til tross for at elevene deres ser ut til å ønske seg mer dans i kroppsøving.

\section{Konklusjon}

I denne artikkelen drøfter vi omfanget av danseundervisning i kroppsøving som en indikator på den operasjonaliserte lereplan opp mot dansens posisjon i den formelle lereplan. På bakgrunn av beskrivelser i formål, hovedområder og antall kompetansemål med danseinnhold konkluderer vi med at dans har en solid posisjon i den formelle lareplan i LK06. Dette bryter med Nordaker (2009) sin analyse av LK06 som dansefaglig alarmerende. De gode intensjonene som ble mer utfyllende beskrevet $\mathrm{i}$ planene fra 1990-årene er til stede også i LK06. Men LK06 har en kort form som krever mer av de skoler og lærere som lokalt skal operasjonalisere planen på en faglig forsvarlig måte. LK06 representerer et brudd, men da mer i form enn i innhold.

Med reservasjoner knyttet til utvalg i videregående skole, selvseleksjon og selvrapportering for lærerne på trinn 1-10, står dette i motsetning til den operasjonaliserte lereplan. Der virker dansen generelt å ha svake vilkår, selv om det varierer noe mellom hovedtrinnene. For trinn 1-4 ser det ut til at det kanskje brukes nok tid til at det kan være mulig for elevene å jobbe med kompetansemålene for dans på en tilfredsstillende måte. Spriket mellom formell og operasjonalisert laereplan på trinn 5-7 gjør dette mindre realistisk. For trinn 8-10 er omfanget av danseundervisning for majoriteten av elevene slik at det ikke er realistisk å bygge den kompetanse i dans som den formelle lereplan foreskriver. For trinn 11-13 sier over halvparten av elevene at de ikke lærer dans eller er med på å skape dans.

Resultatene i evalueringen av L97 ved Jacobsen et al. (2006) pekte på at det var en tendens at dans var i ferd med å forsterke sin posisjon i kroppsøvingsfaget. Våre resultater gir ikke grunnlag for å konkludere om denne tendensen har utviklet seg videre eller ikke, men det ser slik ut på trinn 1-4. Hvis det er en bevegelse i retning forsterket posisjon på andre trinn, så foregår den i tilfelle svært langsomt. 
Undersøkelsen viser at avstanden mellom formell og operasjonalisert lereplan for dans i kroppsøvingsfaget er problematisk stor gjennom hele skoleløpet, med unntak av trinn 1-4. Avstanden ser ut til å øke jo høyere en kommer opp i skolesystemet, men her må vi reservere oss med tanke på utvalget på videregående trinn. konklusjonen er at dans i kroppsøving for et flertall av norske elever er langt mindre enn de gode intensjonene i den formelle lereplan. Skal en få til et dansefaglig og pedagogisk utviklingsarbeid som møter denne utfordringen, må ikke bare kroppsøvingslærere, men også skoleledelse og skoleeier ut på gulvet.

\section{Biographies}

Trond Egil Arnesen er førstelektor ved Høgskulen på Vestlandet, campus Stord, der han underviser i kroppsøving i grunnskolelærerutdanningene, praktisk pedagogisk utdanning og barnehagelærerutdanning. Forskningsfeltet hans er kroppsøvingsdidaktikk. Han har også jobbet med kroppsøving og idrettsfag i videregående skole.

Petter Erik Leirhaug er førsteamanuensis ved Høgskulen på Vestlandet, campus Sogndal. Forskning og undervisning er knyttet til lærerutdanningene og bachelor- og mastergradsstudiene innen friluftsliv, idrett og kroppsøving. Han har bakgrunn som lærer i grunnskole og vidaregående skule og har skrevet doktorgrad om vurdering for læring i kroppsøving ved Norges idrettshøgskole.

Helga Aadland er førstelektor ved Høgskulen på Vestlandet, campus Stord, der hun underviser i kroppsøving i grunnskolelærerutdanningene og forsker på kroppsøvingsdidaktikk. Hun har jobbet som allmennlærer i barneskolen og med kroppsøving og idrettsfag i videregående skole.

\section{Litteraturliste}

Arnesen, T.E. (2010). IKT i kroppsøving på ungdomstrinnet (s. 258-279). I: Vavik, L., Andersland, S., Arnesen, T.E., Arnesen T., Espeland, M., Flatøy., Grønsdal, I., Fadnes, P., Sømoe, K. \& Tuset, G.A. (2010). Skolefagsundersøkelsen 2009. Utdanning, skolefag og teknologi. HSH-rapport 2010/1. Stord: Høgskulen Stord/Haugesund.

Arnesen, T.E. \& Aadland, H. (2013). Kroppsøving på barnetrinnet - vektlegging av leik og rørsleglede (s. 29-68). I: M. Espeland, T.E. Arnesen, I.A. Grønsdal, A. Holthe, K. Sømoe, H. Wergedahl \& H. Aadland (red.). Skolefagsundersøkelsen 2011. Praktiske og estetiske fag på barnetrinnet $i$ norsk grunnskule. HSH-rapport 2013/7. Stord: Høgskulen Stord/Haugesund.

Björksten, E. (1918). Kvinnogymnastik. Helsingfors: Holger Schildts Förlag.

De Vaus, D.A. (2014). Surveys in social research (6th Edition). London: Routledge.

Espeland, M., Arnesen, T.A., Grønsdal, I.A., Holthe, A., Sømoe, K., Wergedahl, H. \& Aadland, H. (2013). Skolefagsundersøkelsen 2011. Praktiske og estetiske fag på barnetrinnet i norsk grunnskule. HSH-rapport 2013/7. Stord: Høgskulen Stord/Haugesund.

Gard, M. (2006). Neither flower child nor artiste be: Aesthetics, ability and physical education. Sport, Education and Society, 11(3), 231-241. doi: 10.1080/13573320600813382.

Goodlad, J.I., Klein, M.F. \& Tye, K.A. (1979). The domains of curriculum and their study. I: J.I. Goodlad and Associates. Curriculum inquiry. The study of curriculum practice (s. 43-76). New York: McGraw-Hill.

Gurholt, K.P. \& Jenssen, R. (2007). Reformpedagogikkens innpass i kroppsøvingsfaget. Norsk Pedagogisk Tidsskrift, 91, 447-479.

Grønmo, S. (2016). Samfunnsvitenskapelige metoder. Bergen: Fagbokforlaget.

Hegna, H. (1938). Kroppsøving i landsfolkeskolen. Oslo: J.W. Cappelens forlag.

Jacobsen, E.B. (2003). «Dans i skolen»: Ønsket eller uønsket? Kroppsøving, 53(6), 6-11.

Jacobsen, E.B., Moser, T., By, I.Å., Fjeld, J., Gundersen, K.T. \& Stokke, R. (2006). L97 og kroppsøvingsfaget fra blå praktbok til grå hverdag? Synteserapport. NFR. Hentet 9.9.2013 fra http://www.forskningsradet.no/ servlet/Satellite?c=Page\&pagename $=$ ForskningsradetNorsk $\% 2$ FHovedsidemal $\&$ cid $=1175003277667 \&$ querystring $=$ jacobsen + kropps $\% \mathrm{C} 3 \% \mathrm{~B} 8$ ving\&spell $=$ true $\&$ filters $=$ cssitename $\% 2 \mathrm{C} \% 21$ Forskningsradet Engelsk \%2C \%2Clangc odes\%2Cno\&isglobalsearch=true\&configuration=nfrsearchersppublished

Kirke- og undervisningsdepartementet. (1974). Mønsterplan for grunnskolen. Oslo: Aschehoug. 


\section{T. E. Arnesen et al.}

Kirke-, utdannings- og forskningsdepartementet. (1994). Lereplan for videregående opplaring: Kroppsøving. Felles allment fag for alle studieretninger. Oslo: Kirke-, utdannings- og forskningsdepartementet.

Kirke-, utdannings- og forskningsdepartementet. (1996). Lareplanverket for den 10-årige grunnskolen. Oslo: Kirke-, utdannings- og forskningsdepartementet.

Koziol, S.M.Jr, \& Burns, P. (1986). Teachers' Accuracy in Self-Reporting about Instructional Practices Using a Focused Self-Report Inventory. The fournal of Educational Research. 79(4), 205-209. Hentet fra https:// www.jstor.org/stable/27540198?seq=1\#page_scan_tab_contents

Kunnskapsdepartementet. (2006). Læreplan i kroppsøving (KRO1-01). Hentet fra https://www.udir.no/k106/ KRO1-01

Laban, R. (1948). Modern educational dance. Suffolk: Macdonald \& Evans.

Lagerstrøm, B.O. (2007). Kompetanse i grunnskolen: hovedresultater 2005/2006. SSB rapport 2007/21. Oslo/ Kongsvinger: Statistisk Sentralbyrå.

Leirhaug, P.E. (2016). «Karakteren $i$ seg selv gir jo ikke noe laring». En empirisk studie av vurdering for laring $i$ kroppsøving ved seks videregående skoler $i$ Norge. Doktoravhandling. Oslo: Norges idrettshøgskole.

Mattsson, T. \& Lundvall, S. (2015). The Position of Dance in Physical Education. Sport, Education and Society, 20(7), 855-887. doi: 10.1080/13573322.2013.837044.

Nordaker, D.J. (2009). Dans $i$ skolen? Doktoravhandling. Aarhus: Aarhus Universitet.

Nordaker, D.J. (2010). Har dans en fremtid i den norske grunnskolen? I Pape, S. (red.) Norsk danseforskning, (s. 81-106), Trondheim: Tapir akademiske forlag.

Sanderson, P. (1996). Dance within the national curriculum for physical education of England and Wales. European Physical Education Review, 2(1), 54-63. doi: 10.1177/1356336X9600200106.

Utdanningsdirektoratet. (2012). Udir-8-2012 Endringer i faget kroppsøving. Rundskriv. Hentet 10.9.2012 frå http://www.udir.no/Regelverk/Rundskriv/2012/Udir82012-Informasjon-om-endringer-i-fagetkroppsoving-igrunnskolen-og-videregaende-opplaring/

Vavik, L., Andersland, S., Arnesen, T.E., Arnesen T., Espeland, M., Flatøy., Grønsdal, I., Fadnes, P., Sømoe, K. \& Tuset, G.A. (2010). Skolefagsundersøkelsen 2009. Utdanning, skolefag og teknologi. HSHrapport 2010/1 Stord: Høgskulen Stord/Haugesund. 